\title{
The Influence Of Green Marketing, Attribute Tourism Products, E- Wom The Visit Decision
}

\section{Muhammad Syarif Hidayatullah Elmas*}

Economic Fakulty of UPM Probolinggo

\section{A R T I C L E I N F O \\ Article history: \\ Received 19 November 2018 \\ Received in revised form 16 December 2018 \\ Accepted 15 January 2019 \\ Available online 26 \\ February 2019}

Keywords:

green marketing, tourism

product attributes, e-wom,

and the visit decision

\begin{abstract}
A B S T R A C T
The research was done in Probolinggo aimed at to investigate the influence among variables green marketing, attribute tourism products, and e-wom on the variables of decision visit tourism objects in Probolinggo. The model of the research uses quantitative with a descriptive model. A values that is green marketing, attribute tourism products, and e-wom as the independent variable and decisions visit as dependent variable. A population that is used all visitors tourism objects in Probolinggo on October 2018 with samples from 80 people. The determination use random sample of sampling. The result of the research show significance value of green marketing is 0,003 , attribute tourism products is 0,000 , and e-wom is 0,690 . So that variable green marketing, attribute tourism products significant its impacts to decision visit, while e-wom influential insignificant of the decision visit.
\end{abstract}

\footnotetext{
* Corresponding author.

E-mail addresses: elmas@upm.ac.id (Muhammad Syarif Hidayatullah Elmas)
} 


\section{Introduction}

People often stuck in their daily routine solid and of course need concentration high, so that a person easily saturated or bored i operate in rainy season. Hence, the need for entertainment and recreation desperately needs every man, because with the entertainment and recreation, can help someone to eliminate their feeling and forget the problems being faced in daily life. So that one can back fresh. One of entertainment and on holiday can be done to conduct tourism.

Tourism defined as a place for on vacation, break, recreation, tourism, or business. Each region must have tourist destinations variegated, in east java especially Probolinggo, having a tourist variegated and can be enjoyed by everyone. It becomes an opportunity for a company to build tourism object that interests visit tourists. But from the many visitors, the majority of them less concerned with the environment. Therefore, is required a identification the environment to know the largest contribution to environmental and efforts to environment protection by the application of the concept of green.

The company would apply the environment for done the marketing, because of the new concept of marketing green (green marketing). With this concept the company can realize tourist destinations more experienced, so we are the visitors can be felt a more refreshing to deprive of feeling and saturated of activity daily. In addition, to give and grades create a added, there should have been attribute tourism products which could result in curiosity. Product of attribute tourism having the function is very important it cause a magnet for every purpose tourism.

Attribute tourism products include facilities, access, and charm. Facilities that supports the concept of green marketing usually live in the toilet, mosques, a parking lot, shelter, means and play. Besides facilities, access to sites is important for visitors to the attraction. Usually good access can look at whether or not the road and easily be a means of transportation to sites that are intended. With the facilities and the accessibility, then can create its own magnetic for visitors, so visitors would tell the impression their has perceived during a visit to the tourist destinations to its closest relative and people one through electronic media.

Electronic media is one of the facilities for promotional activities directly or do not bear it directly. A promotion that has an indirect via an electronic medium commonly called e-wom. People who has visited become the favorite tourist destinations usually shared with us some of and nana were having a that tourism place to the near of kin or the people he loved. Without anybody being aware they have wrought confusion campaign to promote bos program be punished and recommend that tourism place. By the presence of the concept of green marketing, the attribute of tour product, and activities e-wom so would hold up progress on this visit to the decision.

Through a number of considerations, the visitor or visitors will pass judgment, whether tourism were suitable to attend or not. With the good the green marketing, tourism product attributes and decent e-wom through a favorable impression, so the decision is likely to visit. While, when green marketing, attributes the e-wom less tourism and give a good impression, it will cause the doubts and small to inflict decision will visit. This study aims to investigate the influence among variables green marketing, attribute products, and e-wom on the variables of decision tourism objects visit in Probolinggo.

Variable relations green marketing on the decision visit

According to Haery, Dehaghi, \& Yazdani (2013) generally the concept of marketing green is the concept of wider that can be focused on the consumer and goods industry or even services. According to brammer in Kusnandar \& Rinandiyana (2016), marketing green was one effort to company in providing an environmentally friendly service. According to Yulianto \& Mawardi, (2017), said that strategy green marketing applied by the company can produce alternative the choice to consumers. Excess green marketing is as a strategy competitive apply the concept of green by using nature. With the separate concepts this will cause curiosity the community so desire for a visit will be even higher. Things which includes in green marketing covering product, price, and promotion (Mayang Pradma Putripeni, Suharyono, 2014). The result on Paysal (2016), explained that variable green marketing significant of the decision the purchase. Research is in line with Agung, Dwipamurti, \& Mawardi (2018) stated variable green marketing have significant impact of the decision the purchase. The survey is also consistent with Yulianto \& Mawardi (2017), stating that the variable green marketing directly influence and significant on variables decision the purchase. So, the hypothesis research proposed is :

H1 : Allegedly green marketing significant on the tourism objects in Probolinggo visit.

The relation of variable attribute tourism products on the decision visit

An attribute of products including thing their interest to their customers, and an essential ingredient as the reference decision making (Onsu, Tawas, \& Repi, 2015). An attribute tourism products is these services are perceived or obtained by travelers since he had gone before them and on their tourist 
destination untill go back. An attribute tourism products provided on a tourist destinations, capable of being be an attraction and the degree of interest for tourists so as to cause a decision to pay a visit. An attribute covering of the attractions of the products, facilities, and accessibility (Ilham Surgawi, 2016). Based on previous studies, namely tourism product attributes set as the independent variable and decisions visit as dependent variable. According to other study (Ilham Surgawi, 2016), shows that variable tourism products possessing a positive influence and significant of the decision visit tourists. Supported also by Mayasari \& Budiatmo, (2017) stated that the variable attribute tourism products influential of the decision visit. And states that attributes products tourism directly influence the decision visit tourist destination :

H2 : The expected tourist products on the significant tourism objects visit in Probolinggo.

The relation of variable e-wom of the decision visit

E-wom is statement customers either positive or negative on a product or service and it has been happening to them through electronic media Suwarduki, Yulianto, \& Mawardi (2016). According to westbrook espoused in Torlak, Ozkara, Tiltay, Cengiz, \& Dulger (2014), The e-wom is communication that provides information to the consumers of products and services through technology based on the internet. Majority of residents gather information through the internet including for reference tourist destinations. Several issues on e-wom based on the research of Mustikasari \& Widaningsih (2016) were the intensity, content, and valence of opinion. To Sari \& Pangestuti (2018) research, shows that e-wom has links with decision stay. Based on the research Heni Susilawati (2017), shows that e-wom significant influential of the decision visit in Taman Sindu Kusuma. Supported also by research Massie (2016), which proves that e-wom significant of the decision consumers buying.

H3 : Electronic-word of mouth have significant impact on the visit tourism objects in Probolinggo.

\section{Method}

This study used a quantitative approach with a model descriptive and use primary data, as well as interviews and questionnaires turnaround is the method. The population of this research is all the visitors tourism objects in Probolinggo in October 2018 were selected from 80 people. The determination of sample districts and the technique does use random sampling and simple random sampling.

\section{Research Stage}

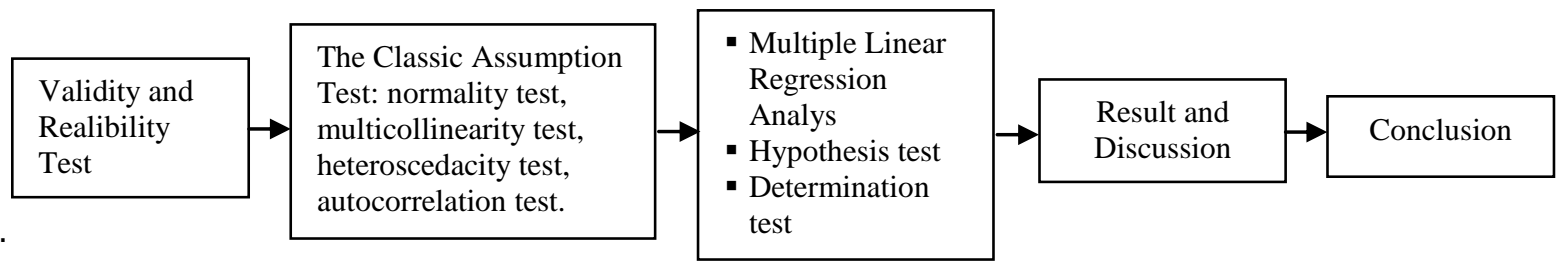

\section{Results and Discussion}

Characteristic of the basis of sex respondents

The basis of sex characteristics data respondents listed in Table 1:

Table 1. The Basis Of Sex Characteristics

\begin{tabular}{llll}
\hline No & Sex & Respondents & $\%$ \\
\hline 1 & Male & 33 & $41,25 \%$ \\
2 & Female & 47 & $58,75 \%$ \\
\multicolumn{2}{l}{ Total } & 80 & $100 \%$ \\
\hline
\end{tabular}

Based on the characteristics of respondents

Source: Primary data 2018

The data based on the respondents residence can be seen in Table 2:

Table 2. Based on the Respondent Residence

\begin{tabular}{llll}
\hline No & Residence & Respondents & $\%$ \\
\hline 1 & Probolinggo City & 16 & $20,0 \%$ \\
2 & Probolinggo district & 50 & $62,5 \%$ \\
\hline
\end{tabular}




\begin{tabular}{lll}
\hline $3 \quad$ Others & 14 & $17,5 \%$ \\
Total & 80 & $100 \%$ \\
\hline
\end{tabular}

Characteristic of respondents based on their age

The data based on the age of the smallest number of respondents can be seen in Table 3 :

Table 3. Based On The Age Respondent

\begin{tabular}{llll}
\hline No & Age & Respondents & $\%$ \\
\hline 1 & $<15$ years old & 30 & $37,5 \%$ \\
2 & $15-30$ years ols & 27 & $33,75 \%$ \\
3 & $>30$ years old & 23 & $28,75 \%$ \\
Total & 80 & $100 \%$ \\
\hline
\end{tabular}

Characteristic the respondents based on work

The data based on the work of the smallest number of respondents be seen in Table 4 :

Table 4. data Based On The Work of Respondent

\begin{tabular}{llll}
\hline No & Work & Respondents & $\%$ \\
\hline 1 & Student & 52 & $65 \%$ \\
2 & Civil servants & 2 & $2,5 \%$ \\
3 & Private Sector workers & 14 & $17,5 \%$ \\
4 & Others & 12 & $15 \%$ \\
\multicolumn{2}{l}{ Total } & 80 & $100 \%$ \\
\hline
\end{tabular}

Characteristic based on fellow visit respondents

The data based on visit respondents seen in Table 5 :

Table 5. Data based on his Visi Respondents

\begin{tabular}{llll}
\hline No & Fellow visit & Respondents & $\%$ \\
\hline 1 & Family & 27 & $33,75 \%$ \\
2 & Friend & 42 & $52,50 \%$ \\
3 & Others & 11 & $13,75 \%$ \\
\multicolumn{2}{l}{ Total } & 80 & $100 \%$ \\
\hline
\end{tabular}

The validity test

The probe for measuring valid whereabouts of a questioner, namely compare $r_{\text {count }}$ with $r_{\text {table. }}$ Grains statement on how to do it is said valid if $r_{\text {count }}>r_{\text {tables }}$ and including on the other hand, so items the statement invalid. Testing use the economic situation of significance 0,05 . The result of testing validity as follow:

Seen from above the validity of testing, the $r_{\text {count }}$ of a whole grains statement $>r_{\text {table }}\left(r_{\text {count }}>0,219\right)$, be explained that a whole grains statement variable for all the research is valid.

Table 6. The ValidityTest

\begin{tabular}{ccccccc}
\hline \multirow{2}{*}{ No Item } & $\mathrm{R}_{\text {count }} \mathrm{X}_{1}$ & $\mathrm{R}_{\text {count }} \mathrm{X}_{2}$ & $\mathrm{R}_{\text {count }} \mathrm{X}_{3}$ & $\mathrm{R}_{\text {count }} \mathrm{Y}$ & $\mathrm{R}_{\text {table }}(5 \%)$ & Description \\
\hline 1 & 0,510 & 0,655 & 0,557 & 0,540 & 0,219 & Valid \\
2 & 0,721 & 0,631 & 0,746 & 0,514 & 0,219 & Valid \\
3 & 0,687 & 0,583 & 0,694 & 0,354 & 0,219 & Valid \\
4 & 0,816 & 0,647 & 0,788 & 0,601 & 0,219 & Valid \\
5 & 0,651 & 0,633 & 0,649 & 0,526 & 0,219 & Valid \\
6 & 0,670 & 0,551 & 0,664 & 0,509 & 0,219 & Valid \\
7 & 0,562 & 0,669 & 0,528 & 0,572 & 0,219 & Valid \\
8 & 0,591 & 0,679 & 0,569 & 0,423 & 0,219 & Valid \\
9 & - & - & - & 0,539 & 0,219 & Valid \\
10 & - & - & - & 0,586 & 0,219 & Valid \\
\hline
\end{tabular}


Source: Primary data processed, 2018

The reability test

The probe is used to measure an indicator of variables on a the questionnaire, it is reliabel when answer respondents of statement consistent over time. To determine an instrument reliabel or not with use constraint $0,6(>0,6)$. The following the result of testing reliability:

Referring to the results above, be said that value cronbach's alpha in all the variables $>0,6$. So, can be explained that all a statement from each variable in this research was reliabel.

Table 7. The Reability Test

\begin{tabular}{lllll}
\hline No & Variable & N of Items & Cronbach's Alpha & Description \\
\hline 1 & Green Marketing & 8 item & 0,799 & Reliabel \\
2 & Tourism product attributes & 8 item & 0,784 & Reliabel \\
3 & Electonic Word of Munth & 8 item & 0,801 & Reliabel \\
4 & The visit decision & 10 item & 0,690 & Reliabel \\
\hline
\end{tabular}

Test of the classical assumption

The probe aimed at testing whether variable this research free from of irregularities. The probe includes:

The Normality test

The probe done to test value residual produced are distributed normally or not.

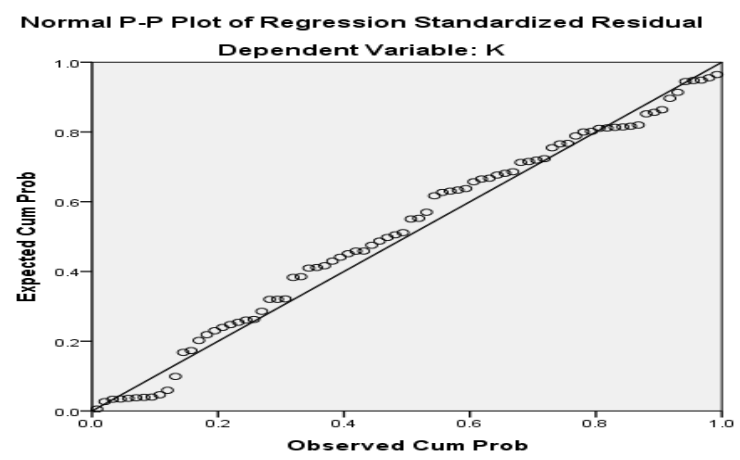

Picture 1. P Plot Regression Diagram

In this data collection referred a picture 1 above, where it has been documented that point of a still in its approach and follow official procedure in diagonal lines so it can be said that normal data distributed.

The Multikolinieritas test

The multikolinieritas done to test model regression is there any correlation between the independent variable. Good regression models when correlation does not occur among the independent, it can be seen with the tolerance value of criteria $>0,1$ and value of VIF $>10$.

Table 8. The Multikolinieritas Test

\begin{tabular}{lllll}
\hline No & Variable & Tolerance & VIF & Description \\
\hline 1 & Green Marketing & 0,445 & 2,246 & Non- Multikolinieritas \\
2 & Tourism product attributes & 0,908 & 1,101 & Non- Multikolinieritas \\
3 & Electonic Word of Munth & 0,425 & 2,353 & Non- Multikolinieritas \\
\hline
\end{tabular}

Based on the results of testing multikolinieritas above, indicate that all of the independent variable tolerance value of $>0,1$ and the VIF $>10$. Then, produced multikolinieritas free of the independent variable.

The Heteroskedastisitas test The probe test model regression does happen dissimilarity variance of residual an event to the second bringing. 


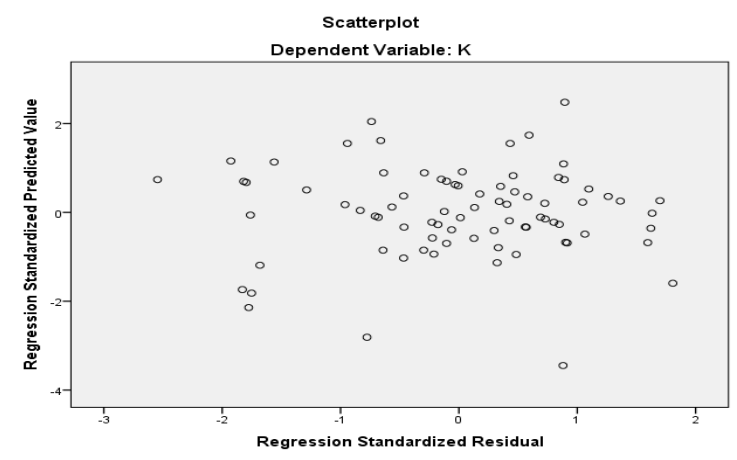

Picture 2. Scatterplot Diagram

Based on a scatterplot picture above, it show that between the dots produced spread and irregular above and beneath the $\mathrm{x}$ axis of 0 on the $\mathrm{y}$ axis. So, it can be said does not occur heteroskedastisitas.

The Autokorelasi test

Regression models such as linking banks which it is hoped was good or free from any autokorelasi. The measurement of autokorelasi adapted to table durbin-watson.

Table 9. The Autokorelasi Test

\begin{tabular}{lllll}
\hline No & Dourbin-Watson & dL & dU & Description \\
\hline 1 & 2,056 & 1,560 & 1,715 & Non-Autokorelasi \\
\hline
\end{tabular}

Source: Primary data processed, 2018.

Based on the results of testing autokorelasi above, can be seen from criteria dU $<$ DW $<4-\mathrm{dU}$ $(1,715<2,056<2,285)$. As a result the probe does not occur autokorelasi.

The Regression analysis linear multiple

This analysis is that done to know existence the influence or relations in a linear manner between variables independent (green marketing, attribute tourism products, and electonic word of mouth) with dependent variable (a decision visit).

Table 10. Value of Beta

\begin{tabular}{ccc}
\hline No & Models & $\beta$ \\
\hline 1 & Contant & 9,560 \\
2 & Green Marketing & 0,368 \\
3 & Tourism product attributes & 0,531 \\
4 & Electonic Word of Mounth & 0,047 \\
\hline
\end{tabular}

Source: Primary data processed, 2018

The equation the regression coefficient linear multiple:

$\mathrm{Y}=\mathrm{a}+\mathrm{b}_{1} \mathrm{X}_{1}+\mathrm{b}_{2} \mathrm{X}_{2}+\mathrm{b}_{3} \mathrm{X}_{3}$

$Y=9,560+0,368 X_{1}+0,531 X_{2}+0,047 X_{3}$

Based on the regression equation is the , it can be explained as follows:

1. Constant value (a) was recorded at 9,560 it means if green marketing variables $\left(\mathrm{X}_{1}\right)$, the attribute of the product tourist $\left(\mathrm{X}_{2}\right)$, and electonic word of mouth $\left(\mathrm{X}_{3}\right)$ there is no, the culprits will be brought obtained the value of a decision which was made as much as 9,560 .

2. Value the regression coefficient beta $\left(b_{1}\right)$ on the variables of green marketing are positive of 0,368 that means that every the addition of business green marketing of product, price, and promotion, so decision visit is increased.

3. Value the regression coefficient beta $\left(b_{2}\right)$ on the variables of attribute tourism products are positive of 0,531 that means that every the addition of attribute of products tourist attraction, facilities, and accessibility so decision visit is increased.

4. Value the regression coefficient beta $\left(b_{3}\right)$ on the variables of electonic word of mouth are positive of 0,047 that means that every increase electonic word of mouth through the intensity, valence of opinion, and content so decision visit is increased. 
The Hypotesis Test

An explanation about the significance (or the levels of trust) with the theory in general $(1 \%, 5 \%$, $10 \%$ ). If the level result of significance enter into one of the many theories thus it can be said the result is that the significant.

Table 11. The Hypotesis Test

\begin{tabular}{cccc}
\hline No & Variable & Sig. & Description \\
\hline 1 & Green Marketing & $0,003^{*}$ & Significance \\
2 & Tourism product attributes & $0,000^{*}$ & Significance \\
3 & Electonic Word of Mounth & 0,690 & Non Significance \\
\hline
\end{tabular}

Source: Primary data processed, 2018

1. The results of the hypothesis testing shows the green marketing variable influence the decision to visiting at tourism objects in Probolinggo. This means that first hypothesis was made available (answered after all).

2. The results of the hypothesis testing shows that the tourism product attributes significant influence the decision to visit on tourism objects in Probolinggo. The second hypothesis received (answered after all).

3. The results of the hypothesis testing shows that the electonic word of mouth variable of influential no insignificant about the decision to visit at tourism objects in Probolinggo. It means third hypothesis is rejected (missed).

The coefficient of determination

That used to assess the relative how strong the fit of the model in clarifying variations dependent variable.

Table 12. Model Summary

\begin{tabular}{lllll}
\hline Model & R & R Square & Adjusted R Square & Std. Error of the Estimate \\
\hline 1 & $.708^{\mathrm{a}}$ & .501 & .481 & 2.91213 \\
a. Predictors: (Constant) & & & & \\
\hline
\end{tabular}

Source : Primary data processed, 2018

According to the table above, obtained the value of adjusted $\mathrm{r}_{\text {square }}$ as much as 0,481 which means the decision to visit influenced green marketing, the attribute of tourist products, and electonic word of mouth as much as $48,1 \%$, the remaining $51,9 \%$ influenced by other variables.

Discussion

The influence of green marketing the decision visit.

The result of hypothesis testing, in accordance with the table of 9 obtained the magnitude of significance of 0,003 which means the green marketing significant on the visit tourism objects in Probolinggo. This is supported by value $t_{\text {count }}$ of $3,095>$ value of $2,642 t_{\text {tabel }}$. This is supported by the concept of a green marketing that may lead to public interest. Be side terms of the concept, it also is supported by the price that still reach leading to visit can affect decision. This result is a line with research Paysal (2016), shows green marketing have significant impact on the decision.

It also consistent with research Agung et al., (2018), who said that the variable green marketing having significant impact of the decision of the purchase. The result of this research is also consistent with research Yulianto \& Mawardi (2017), that the variable green marketing having significant impact on the variables of the purchase decision.

The influence of attributes tourism products on the decision visit.

Based on the result of the second hypothesis testing, in accordance with the table of 9 obtained the amount of the significance of 0,000 so it can be explained variable attribute tourism products also have significant impact of the decision of visiting at tourism objects in Probolinggo. This is that supported have followed your value $t_{\text {count }}$ as much as 5,691 denoting $>$ value $2.642 t_{\text {table }}$ as much as.This is reflected in the high number of shelter for visitors who want to for a moment rest and the large number of spot and take a picture. Because the majority of visitors to enshrine every can not be separated from the moment so that it can be affecting decision visit. This is same with research Ilham Surgawi (2016), that shows the product tourism proven have had a positive impact and significant of the decision visit tourists. Then also 
supported by research Mayasari \& Budiatmo (2017), that the variable attribute tourism products have leverage of the decision visit.

The influence of electonic word of mouth on the decision visit.

Based on the results of the third hypothesis testing, in accordance with the table of 9 obtained the magnitude of significance of 0,690 that means variable electonic word of mouth no significant on the visit on tourism objects in Probolinggo. The result of this research is not consistent with previous studies by Sari \& Pangestuti (2018), showing electronic word of mouth links with the decision to stay. In addition, it also not consistent with research Heni Susilawati (2017), showing electronic word of mouth significant of the decision on park visit Sindu Kusuma. But, consistent with research Suwarduki et al., (2016), indicating that electronic word of mouth having influence insignificant of the decision visit. The other happen to research Wijaya \& Paramita (2014), that the impact of electronic word of mouth not significant of the decision of the purchase. E-wom is not influence the decision visit because most of the visitors do not know tourism objects in Probolinggo of electronic media but more know very much by word of mouth. It was because Probolinggo still included in section that is still thriving.

\section{Conclusion}

The conclusion of this study that green marketing and attributes tourism products have significant impact of the decision of a decision visit. While, electronic word of mouth to have an influence of the decision of insignificant visiting at tourism objects in Probolinggo.

For the next researchers, let expand or increase the independent variable another in research future that must be also affect dependent variable both in the same object and different. So that required to be added other variables to equip and paints a clearer about the independent variable that influence the dependent variable.

\section{Refrence}

Agung, I. G., Dwipamurti, N., \& Mawardi, M. K. (2018). THE EFFECT OF GREEN MARKETING ON BRAND IMAGE AND PURCHASE ( Study on Consumer of Starbucks Café Ubud , Gianyar Bali ), 61(3), 57-64.

Haery, D. F. A., Dehaghi, D. M. R., \& Yazdani, A. (2013). Effect of Green Marketing on Consumer Purchase Intentions With Regard to the Company's Image as a Mediator in the Retail Setting Case study: The Customers of Naghshe-e Jahan Sugar Company. International Journal of Academic Research in Business and Social Sciences, 3(11), 442-452. https://doi.org/10.6007/IJARBSS/v3-i11/356

Heni Susilawati. (2017). Pengaruh Electronic Word Of Mouth Terhadap Keputusan Berkunjung Di Sindu Kusuma Edupark. Jurnal Khasanah Ilmu, 8(2), 32-39.

Ilham Surgawi, S. (2016). PROMOSI TERHADAP KEPUTUSAN WISATAWAN DALAM MENGUNJUNGI OBJEK WISATA ( Studi pada Objek Wisata Puri Maerokoco Kota Semarang ). Diponegoro Journal of Management, 5, 1-10.

Kusnandar, D. L., \& Rinandiyana, L. R. (2016). The influence of green marketing on consumer purchase behavior. Environmental Economics, 7(2), 77-85. https://doi.org/10.21511/ee.07(2).2016.8

Massie, K. S. (2016). the Effect of Social Media, Direct Email, and Electronic Word-of Mouth (E-Wom) on Consumer Purchase Decision At Zalora Fashion Online Store. The Effect Of... Jurnal EMBA, 714(2), 714-725.

Mayang Pradma Putripeni, Suharyono, andriani K. (2014). Trends of changes in the botanical diversity under the influence of desertification in the republic of Kalmykia. Jurnal Administrasi Bisnis, 10(1), 1-10. https://doi.org/10.1134/S2079096114020024

Mayasari, W. M., \& Budiatmo, A. (2017). PENGARUH ATRIBUT PRODUK WISATA DAN WORD OF MOUTH TERHADAP KEPUTUSAN BERKUNJUNG PADA OBJEK WISATA TAMAN Pendahuluan Setiap manusia memiliki berbagai macam kebutuhan, salah satunya adalah rekreasi atau berwisata, yaitu melakukan kegiatan perjalanan dengan. Jurna Administrasi Bisnis, 6(1), 1-8. 
Mustikasari, A., \& Widaningsih, S. (2016). THE INFLUENCE OF e-WOM ON THE DECISION COMES TO THE. Jurnal Manajemen Indonesia, 16, 95-103. https://doi.org/https://doi.org/10.25124/jmi.v16i2.315.

Onsu, R., Tawas, H., \& Repi, L. (2015). Atribut Produk, Citra Merek, Dan Strategi Promosi Pengaruhnya Terhadap Keputusan Pembelian Sepeda Motor Di Dealer Yamaha Ranotana. Jurnal EMBA, 3(2), 818-828.

Paysal, S. A. R. A. (2016). Pengaruh Green Marketing Terhadap Keputusan Pembelian Pada Produk Nike di Bandung Tahun 2016. E-Proceeding of Applied Science, 2(3), 771-777. https://doi.org/10.1021/ja103110y

Sari, F., \& Pangestuti, E. (2018). Pengaruh Electronic Word Of Mouth ( E-wom ) Terhadap Minat Berkunjung Dan Keputusan Berkunjung ( Studi Pada Wisata Coban Rais BKPH Pujon ). Jurnal Administrasi Bisnis, 54(1), 189-196.

Suwarduki, P. R., Yulianto, E., \& Mawardi, M. K. (2016). Pengaruh Electronic Word Of Mouth Terhadap Citra Destinasi Serta Dampaknya Pada Minat dan Keputusan Berkunjung. Jurnal Administrasi Bisnis, 37(2), 1-10.

Torlak, O., Ozkara, B. Y., Tiltay, M. A., Cengiz, H., \& Dulger, M. F. (2014). The Effect of Electronic Word of Mouth on Brand Image and Purchase Intention: An Application Concerning Cell Phone Brands for Youth Consumers in Turkey Eskisehir Osmangazi University University of Nevada. Journal of Marketing Development and Competitiveness, 8(2), 61-68. https://doi.org/10.1108/02634501211231946

Wijaya, T., \& Paramita, L. (2014). PENGARUH ELECTRONIC WORD OF MOUTH ( eWOM ) TERHADAP KEPUTUSAN PEMBELIAN KAMERA DSLR. Econimics and Business, 9(Sancall), 12-19. Retrieved from http://repository.uksw.edu/handle/123456789/5668

Yulianto, E., \& Mawardi, M. K. (2017). PENGARUH GREEN MARKETING TERHADAP KEPUTUSAN PEMBELIAN DAN DAMPAKNYA TERHADAP LOYALITAS PELANGGAN ( Survei Pada Mahasiswa Universitas Brawijaya Malang Pelanggan Teh Kotak ). Jurnal Administrasi Bisnis (JAB), 47(2). 